Котик О. В., старший викладач кафедри фінансів та економіки природокористування,

Любовська М. М., здобувач вищої освіти другого (магістерського) рівня

(Національний університет водного господарства та природокористування, м. Рівне)

\title{
ЗАГРОЗИ ТА РИЗИКИ ФІНАНСОВОЇ БЕЗПЕКИ БАНКІВ ТА ШЛЯХИ ЇХ УСУНЕННЯ
}

У статті розглянуто зміст понять «фінансова безпека банку», «ризик», «загроза», а також досліджено їх взаємозв'язок. Проаналізовано основні загрози складових фінансової безпеки банку, визначено їх пріоритетність та запропоновано основні засоби їх захисту та усунення. Розглянуто класифікацію загроз банківській безпеці, що формуються екзо- та ендогенними факторами, з урахуванням сучасних тенденцій підвищення впливу техногенних факторів та загострення конфліктів різних рівнів, таких як військові, корпоративні, засновницькі, банк - персонал, банк - клієнт. Проведено аналіз статистичних даних роботи банківської системи в сучасних кризових умовах. Зроблено критичний аналіз діагностики діяльності банків відповідно до методики Національного банку України.

Ключові слова: фінансова безпека банку; загроза; ризик; зовнішні та внутрішні загрози фінансовій безпеці банку.

Постановка проблеми. Банківська система пов'язана 3 ризиком, що може бути спричинений можливим витоком інформації, зловживаннями працівників, зовнішніми загрозами. Стан сучасного вітчизняного фінансового ринку, недосконалість законодавства, зниження доходів населення і бізнесу, зростання рівня безробіття це причини, через які з'являються нові загрози банківській діяльності. Належний рівень фінансової безпеки банків можливий лише за умови ефективної системи виявлення, класифікації, локалізації загроз і регулювання ризиків банківської системи.

Аналіз останніх досліджень і публікацій. За останні роки все більша кількість науковців приділяє свою увагу дослідженню економічної безпеки банку, зокрема фінансової безпеки, як іï основної складової. Як показав огляд економічної літератури, проблемам дослідження фінансової безпеки банків приділяли увагу такі вчені, як С. Васильчак, Ю. Голобородько, Л. Добрик, І. Крупка, 
Т. Момот, Н. Євченко, О. Криклій, Н. Зачосова, В. Соловйов та ін. Серед зарубіжних вчених, які досліджували дану проблематику, доцільно відмітити В. Гамзу, В. Окейна, І. Ткачука, І. Шумпетера та ін.

Постановка завдання. Метою статті $€$ класифікація загроз та ризиків системи фінансової безпеки банків та визначення основних заходів їх усунення та нейтралізації.

Виклад основного матеріалу. На сьогодні в наукових джерелах не існує єдиного підходу до визначення поняття фінансової безпеки банку. Кожен 3 авторів пропонує та обґрунтовує свій підхід до визначення цього поняття, тому, попри деякі суперечності, варто розглянути основні з них. Систематизацію підходів до трактування поняття «фінансова безпека» представлено в табл. 1.

Таблиця 1

Визначення поняття «фінансова безпека банку»

\begin{tabular}{|c|c|}
\hline Автор, джерело & Визначення \\
\hline $\begin{array}{c}\text { Васильчак С.В. } \\
\text { [1] }\end{array}$ & $\begin{array}{l}\text { «це стан, за якого забезпечується економічний } \\
\text { розвиток і стабільність діяльності банку, } \\
\text { гарантований захист його ресурсів, здатність } \\
\text { адекватно і без істотних втрат реагувати на зміни } \\
\text { внутрішньої і зовнішньої ситуації» }\end{array}$ \\
\hline $\begin{array}{r}\text { Голобород } \\
\text { Ю. О. [2 }\end{array}$ & $\begin{array}{l}\text { «це стан, який характеризується оптимальним } \\
\text { рівнем залучення і розміщення ресурсів при } \\
\text { мінімізації загроз та негативних явищ і } \\
\text { характеризує здатність банків до саморозвитку, } \\
\text { підвищення ефективності та конкурентоздатності» }\end{array}$ \\
\hline $\begin{array}{r}\Theta_{B L} \\
\text { Крик } \\
\text { Зачо }\end{array}$ & $\begin{array}{l}\text { «це такий його фінансовий стан, який } \\
\text { характеризується збалансованістю системи } \\
\text { фінансових показників, стійкістю до внутрішніх і } \\
\text { зовнішніх загроз, що дозволяє своєчасно та в } \\
\text { повному обсязі виконувати взяті на себе } \\
\text { зобов'язання, а також забезпечує ефективний } \\
\text { розвиток банкув поточному та наступних періодах» }\end{array}$ \\
\hline $\begin{array}{c}\text { Соловйов В.І. } \\
\text { [11] }\end{array}$ & $\begin{array}{l}\text { «це стан під час якого забезпечується стабільність } \\
\text { його функціонування, фінансова рівновага і } \\
\text { регулярне одержання прибутку, можливість } \\
\text { виконання поставлених цілей і завдань, здатність } \\
\text { до дальшого розвитку й удосконалення» }\end{array}$ \\
\hline $\begin{array}{c}\text { Стрельбицька Л.М. } \\
\text { [12] }\end{array}$ & $\begin{array}{l}\text { «це здатність протистояти деструктивним змінам на } \\
\text { фінансовому ринку і забезпечити виживання в } \\
\text { конкурентній боротьбі банківського бізнесу» }\end{array}$ \\
\hline
\end{tabular}

Аналіз наявних визначень показав, що більшість науковців під фінансовою безпекою розуміють стан банківської установи, за якого забезпечується економічний розвиток і стабільність діяльності 
банку. При цьому безпека банку передусім $€$ його якісною характеристикою і характеризує його стан як стан, за якого відсутні небезпеки. Ми пропонуємо таке визначення: «Фінансова безпека банку - це динамічний стан банку, що характеризується стабільною захищеністю його фінансових інтересів від зовнішніх та внутрішніх загроз та здатністю забезпечувати реалізацію своїх фінансових інтересів і завдань».

Постійна зміна фінансово-економічної безпеки підприємства залежить від впливу чинників і загроз внутрішнього та зовнішнього середовищ. На сьогодні існує певний спектр загроз та небезпек, які здійснюють негативний вплив на діяльність банку. Виходячи з цього, їм необхідно визначити суму ризику і збитків, які може понести підприємство (банк), визначити ймовірність їх виникнення, оцінити стан робіт щодо запобігання небезпек і загроз, а також можливість усунення їх, розробляючи заходи щодо виправлення становища, уникаючи втрат, які можуть з'явитися.

Відсутність чіткої інтерпретації концепції ризику пояснюється багатовимірністю цього явища, ігноруванням його в чинному законодавстві, а в деяких випадках - обмеженим застосуванням у реальній економічній практиці й управлінській діяльності підприємства. Ризик - це складне явище, невід'ємна приналежність ринкової економіки, який потрібно враховувати в будь-якій сфері діяльності.

Саме поняття «ризик» визначає можливість настання несприятливої події і, здебільшого, інтерпретується як імовірність або загроза втрати деяких своїх ресурсів суб'єктами, втрати доходу чи додаткових витрат у результаті виробничої або фінансової діяльності. При класифікації ризиків всі вчені сходяться на думці, що ризики діляться на внутрішні і зовнішні, але типологія ризиків істотно відрізняється [4].

Термін «ризик» і термін «загроза» в науковій економічній літературі близькі. Ці поняття взаємопов'язані, але принципово різні.

Відоме тлумачення поняття «загроза» включає в себе прояв джерела загрози: «Загроза - виражається в будь-якій формі наміру завдати фізичної, матеріальної чи іншої шкоди суспільним чи особистим інтересам» [9], відповідно загроза економічної / фінансової безпеки банку - чи то існуюче, чи то потенційно можливе явище або фактор, що створює небезпеку для реалізації фінансових інтересів підприємства і не дозволяє виконувати на належному рівні роботу відповідно до домовленості. 3 цією метою при створенні системи фінансової i економічної безпеки виявляють джерела небезпек (загроз), які можуть призвести до ризику. Джерела небезпеки (загрози) - сукупність умов і факторів, що тримають у собі 
і за певних умов самі по собі або в будь-якій комбінації, утворюють деструктивний характер (сукупність негативних впливів).

Розглянемо класифікацію загроз фінансовій безпеці банку, що формуються внутрішніми та зовнішніми факторами, з урахуванням сучасних тенденцій підвищення впливу техногенних факторів та загострення конфліктів на різних рівнях, таких як військовий, корпоративний, засновницький, банк - персонал, банк - клієнт (табл. 2)

Таблиця 2

Загрози для фінансової безпеки банків

\begin{tabular}{|c|c|}
\hline $\begin{array}{c}\text { Зовнішні загрози, що } \\
\text { формуються } \\
\text { екзогенними факторами }\end{array}$ & $\begin{array}{c}\text { Внутрішні загрози, що формуються } \\
\text { екзогенними факторами }\end{array}$ \\
\hline \multicolumn{2}{|c|}{ 1. Природні фактори } \\
\hline $\begin{array}{l}\text { 1.1. Стихійні лиха } \\
\text { 1.2. Природні катаклізми }\end{array}$ & \\
\hline \multicolumn{2}{|c|}{ 2. Технологічні фактори } \\
\hline $\begin{array}{l}2.1 \text { Зовнішні кібератаки } \\
2.2 \text { Стрибки або відключення } \\
\text { електроенергії }\end{array}$ & $\begin{array}{l}\text { 2.1. Застаріле обладнання } \\
\text { 2.2. Відставання від змін у } \\
\text { програмному забезпеченні для } \\
\text { фінансових транзакцій } \\
\text { 2.3. Поганий захист інформації } \\
\text { 2.4. Громіздка та негнучка система } \\
\text { 3бору та обробки даних } \\
\text { 2.5. Відсутність зворотного зв'язку } \\
\text { між підрозділами } \\
\text { 2.6. Збої в технологічному процесі }\end{array}$ \\
\hline \multicolumn{2}{|c|}{ 3. Антропогенні фактори } \\
\hline $\begin{array}{l}\text { 3.1. Економічні: } \\
\text { - несприятлива (кризова) } \\
\text { загальноекономічна ситуація в } \\
\text { країні і регіонах; } \\
\text { - висока інфляція та інфляційні } \\
\text { очікування; } \\
\text { - коливання курсу національної } \\
\text { валюти і паніка населення; } \\
\text { - високі вимоги національного } \\
\text { банку до кредитних операцій; } \\
\text { - зростання зовнішнього і } \\
\text { внутрішнього державного і } \\
\text { комерційного боргу; } \\
\text { - недобросовісна конкуренція на } \\
\text { фінансовому та кредитному }\end{array}$ & $\begin{array}{l}\text { 3.1. Управлінські: } \\
\text { - конфлікти між власниками банку; } \\
\text { - некваліфіковане управління, } \\
\text { помилки в стратегічному плануванні } \\
\text { та прогнозуванні банківської } \\
\text { діяльності; } \\
\text { - низька якість аналітичного } \\
\text { обґрунтування управлінських рішень } \\
\text { при аналізі власного капіталу і } \\
\text { прибутку; } \\
\text { - низька якість маркетингової } \\
\text { обробки ринку банківських послуг; } \\
\text { - прорахунки в оцінці потенційних } \\
\text { позичальників; } \\
\text { - низька якість фінансових ресурсів }\end{array}$ \\
\hline
\end{tabular}


продовження табл. 2

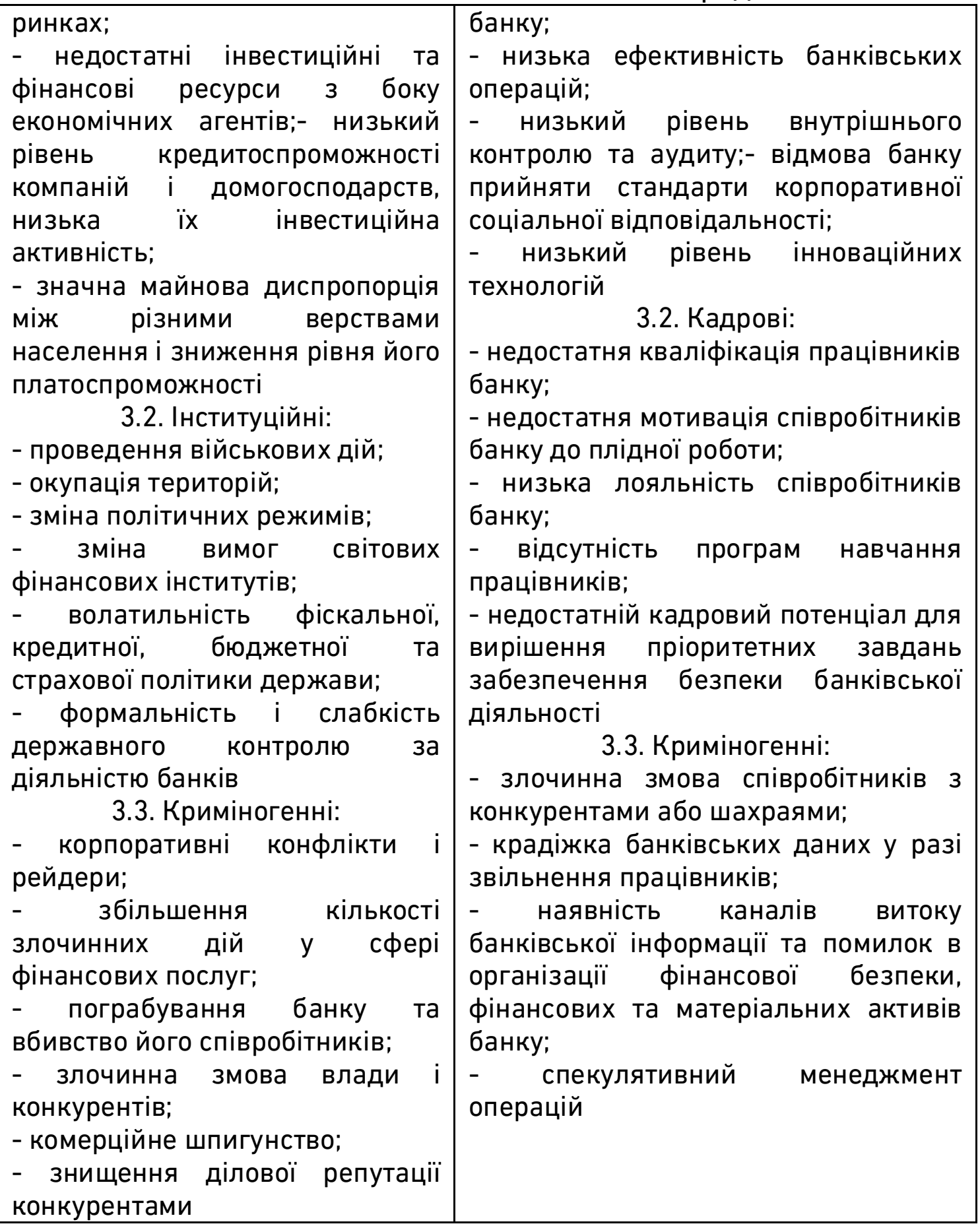

Джерело: складено на основі [3; 4; 12]

Під час визначення фінансової безпеки банків використовується індексу фінансового стресу (далі - ІФС). Цей індекс вимірює рівень стресу фінансової системи та забезпечує комплексну кількісну оцінку їі стану. ІФС дає можливість порівняти поточний стан фінансової системи зі значеннями за попередні періоди та під час минулих криз, оцінити ефективність заходів, спрямованих на 
зменшення системного стресу, а також може бути показником закінчення фінансової кризи.

Вплив зовнішніх та внутрішніх загроз на зміну індексу фінансового стресу за 10 років можемо побачити на рис. 1. Індекс фінансового стресу (ІФC) майже рік був на порівняно низькому рівні. Тим не менше, після рішення суду першої інстанції про приватизацію Приватбанку в кінці квітня 2016 року, ІФС певний час зростав, зокрема через погіршення ліквідності банківського сектору.

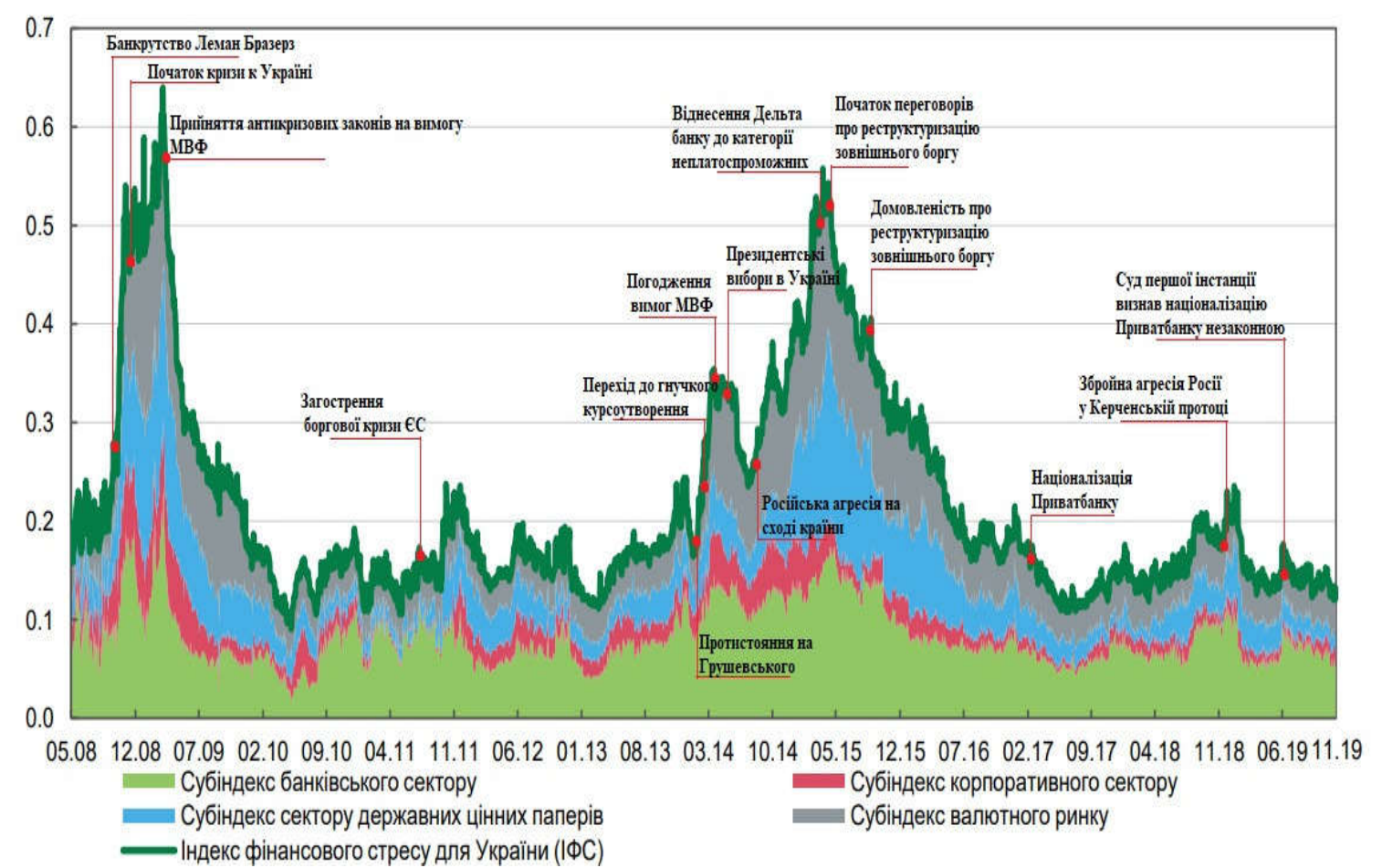

Рис. 1. Індекс фінансового стресу за 2008-2019 рр. та внески субіндексів до його зміни

Джерело: сформовано за допомогою оцінок НБУ [7]

На рис. 1 також відображені субіндекси до Індексу фінансового стресу. Корпоративний субіндекс за останнє півріччя теж незначно зріс. Субіндекс державних цінних паперів мав протилежну тенденцію. Його значення зменшилось за останній рік, що свідчить про зниження суверенних ризиків. Субіндекс валютного ринку відзначався мінливістю, але це не вплинуло на тенденцію ІФС. ІФС відображає лише поточний стан справ у фінансовому секторі та не вказує на майбутні ризики у коротко- чи довгостроковій перспективі.

Розглянемо детальніше умови та ризики банківського сектору (рис. 2). НБУ оцінює ризики за шкалою від 0 до 10, де 0 - найнижчий рівень ризику, 10 - найвищий рівень ризику. Оцінка відображає очікуваний стан на наступні 6 місяців. 


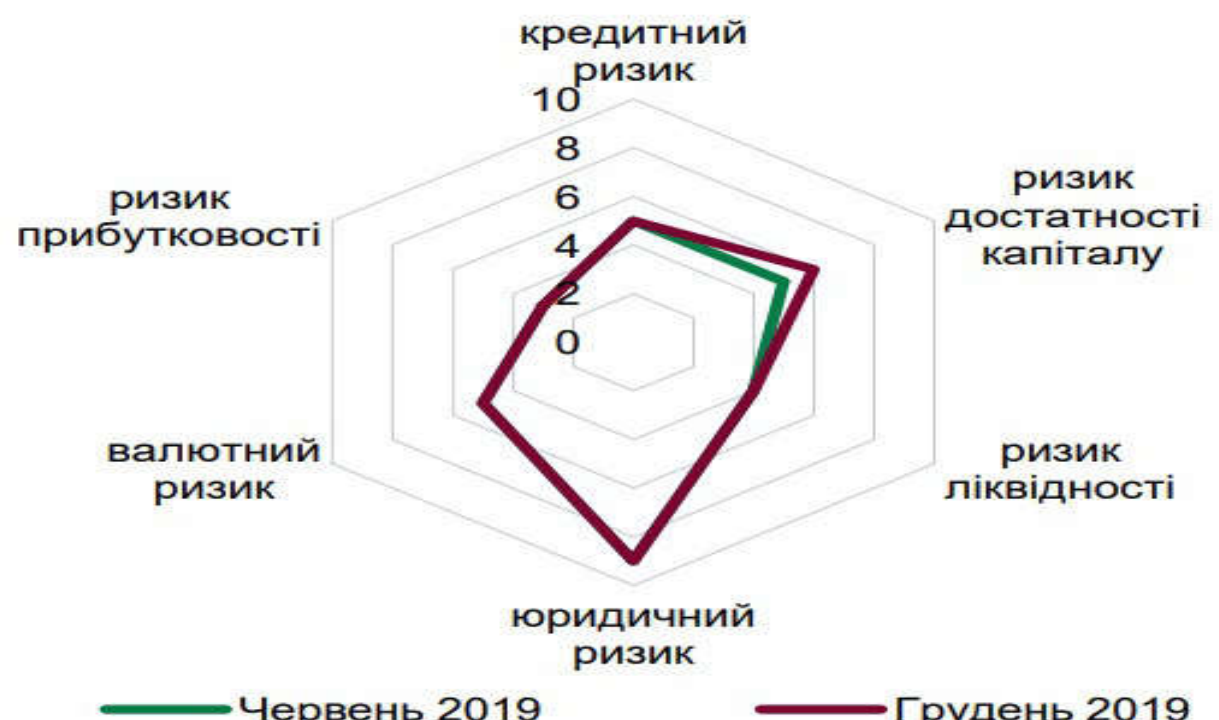

Рис. 2. Карта ризиків банківського сектору

Джерело: оцінки НБУ [7]

Кредитний ризик відображає перспективи зміни рівня непогашених кредитів у портфелях банків та необхідність додаткового формування резервів під такі позики. Зростання рівня прибутковості корпорацій та доходів населення сповільнюється. Більшість компаній реального сектору зменшила боргове навантаження, але $€$ ще багато фінансово слабких позичальників банків, які проводять реструктуризації. У роздрібному сегменті пом'якшуються стандарти кредитування. Подекуди практики оцінки ризиків за незабезпеченими споживчими кредитами $\epsilon$ недостатньо консервативними.

Ризик достатності капіталу оцінює здатність банків забезпечити належний рівень капіталу. Стресові випробування у 2019 році показали, що деякі банки не змогли підвищити фінансову стабільність порівняно 32018 р. Їх капіталізація $€$ достатньою в сучасних умовах, але вони не мають запасу міцності у випадку кризи. Зокрема, це проблема для двох державних банків. Із посиленням вимог до капіталу та запровадженням капітальних буферів ризики для цих банків зростають.

Ризик ліквідності показує здатність банків повністю та своєчасно виконувати свої зобов'язання перед вкладниками та кредиторами. Структурний надлишок ліквідності на фінансовому ринку зберігається. Банківський сектор працює в умовах надлишкової ліквідності; більшість банків виконує норматив LCR зі значним запасом. Водночас конкуренція за зобов'язаннями депозитами корпорацій та населення - залишається високою, що 
зменшує процеси, які призводять до здешевлення ОФ. Коротка структура пасивів залишається системним ризиком сектору [7].

Юридичний ризик оцінює здатність банків захищати власні інтереси, використовуючи юридичні інструменти. Тенденції $\epsilon$ багатонаправленими: прийнято низку законів, необхідних для фінансового сектору, зокрема про «спліт», захист прав споживачів, а також подовжено дію закону про фінансову реструктуризацію. Також позитивною $є$ перша практика застосування нового законодавства для захисту прав кредиторів. Однак судова практика вирішення суперечок між банками та позичальниками все ще $\epsilon$ двоякою. Юридичні ризики, пов'язані із оскарженням націоналізації Приватбанку, залишаються високими [7].

Валютний ризик вказує на те, наскільки тенденції на валютному ринку можуть вплинути на фінансові показники банків. Частка валюти в активах та пасивах банків зросла за останні півроку, банки стали більш охоче кредитувати підприємства в валюті. Водночас відкриті валютні позиції банків зараз не становлять для них значних ризиків, а зовнішній борг банків не зростає [7].

Ризик рентабельності відноситься до здатності банків отримувати чистий дохід. Умови праці банків залишаються сприятливими, рентабельність власного капіталу на історично високому рівні, але в майбутньому знизиться. Темпи зростання комісійних доходів уповільнюються, відсоткова маржа стане меншою, оскільки існує цикл послаблення грошово-кредитної політики та зниження процентних ставок [7].

В «Звіті про фінансову стабільність», від червня 2016 року, було проаналізовано дані, які відповідали міжнародним стандартам, відповідно до них банківська система України минула найглибшу кризову яму та проявляє помітні ознаки відновлення своєї роботи, проте вони є незначними. Проведемо аналіз динаміки основних показників банківського сектору економіки України (табл. 3).

Варто зазначити, що за підсумками 2019 року активи банківської системи України збільшились, проте несуттєво. Їх обсяг станом на 01.03.2020 р. відповідав 2,032 млрд грн проти 1,911 млрд грн на початок року. Кількість банків 3 іноземним капіталом зменшилась на один. Одним з ключових чинників волатильності активів банківської системи протягом аналізованого періоду була динаміка курсу національної валюти поряд з висновком деяких комерційних банків з ринку, рухом коштів клієнтів і скороченням кредитних портфелів. 
Таблиця 3

Динаміка основних показників діяльності банків України

\begin{tabular}{|l|c|c|c|c|}
\hline \multicolumn{1}{|c|}{ Показники } & 2016 р. & 2017 р. & 2018 р. & 01.03 .2020 р. \\
\hline Кількість діючих банків & 96 & 82 & 77 & 75 \\
\hline $\begin{array}{l}\text { з них: з іноземним } \\
\text { капіталом }\end{array}$ & 38 & 38 & 37 & 35 \\
\hline $\begin{array}{l}\text { Загальні активи (не } \\
\text { скориговані на резерви за } \\
\text { активними операціями), } \\
\text { млн грн }\end{array}$ & 1737272 & 1839958 & 1910614 & 2032304 \\
\hline $\begin{array}{l}\text { Загальні активи (не } \\
\text { скориговані на резерви за } \\
\text { активними операціями) в } \\
\text { іноземній валюті, млн грн }\end{array}$ & 788253 & 755191 & 778773 & 747079 \\
\hline Готівкові кошти, млн грн & 36201 & 44099 & 46941 & 49860 \\
\hline Надані кредити, млн грн & 1005923 & 1036745 & 1118860 & 1032703 \\
\hline $\begin{array}{l}\text { Вкладення в цінні папери } \\
\text { та довгострокові інвестиції, } \\
\text { млн грн }\end{array}$ & 332273 & 425803 & 480615 & 568933 \\
\hline Пасиви, млн грн & 1256299 & 1333831 & 1359703 & 1536086 \\
\hline Власний капітал, млн грн & 123784 & 161108 & 154960 & 217153 \\
\hline $\begin{array}{l}\text { Зобов'язання банків, } \\
\text { млн грн }\end{array}$ & 1132515 & 1172723 & 1204 & 1318933 \\
\hline Рентабельність активів, \% & $-12,60$ & $-1,93$ & 1,69 & 6,25 \\
\hline Рентабельність капіталу, \% & $-116,74$ & $-15,84$ & 14,67 & 45,63 \\
\hline
\end{tabular}

Джерело: складено на основі [10]

Високий вплив коливань курсу національної валюти на обсяг активів БСУ пояснюється значною часткою активів в іноземній валюті в загальному обсязі (36,8\% станом на 01.03.2020р.).

Суттєве збільшення власного капіталу на 75,43\% у 2019 р. порівняно із даними 2016 р. веде до покращення економічних нормативів діяльності банків та збільшення індикаторів фінансової стійкості.

На сьогодні банківський сектор отримує рекордні прибутки. Завдяки високій операційній ефективності і низькій вартості кредитного ризику на 01.03.2020 р. рентабельність капіталу сектору (ROE) досягла 45\%, а рентабельність активів змінилась 3 позначки «-» на «+», і досягла у 2019 р. значення 6,25\%.

Ми вважаємо, що надійний банк насамперед повинен мати стабільний фінансовий стан, тобто мати стан фінансових ресурсів та рівень їх використання, при якому, діючи в межах прийнятного 
ризику, вільно маневруючи грошима, він може забезпечити постійне та своєчасне надання банківських послуг, виконання своїх зобов'язань, а також мати достатньо коштів для свого інноваційного розвитку. Більше того, стабільність банку залежить від рівня його фінансової безпеки і формується під впливом як зазначених загроз, так і багатьох інших факторів і має складну структуру, включаючи комерційну стабільність, функціональну стабільність, організаційнуструктурну стабільність, стабільність капіталу, стабільність фінансової діяльності [3]. Загалом, для підвищення рівня безпеки банківських установ необхідно здійснити:

- розробку моделі безпеки для банківських установ як сукупності офіційно прийнятих поглядів, установ (організацій, відносин та пов'язаних з ними дій) шляхом прийняття на державному рівні концепції, стратегії безпеки банківського сектора національної економіки та конкретної програми її підтримки з метою створення методологічної та правової бази для суб'єктів, відповідальних за розробку та реалізацію фінансової, грошовокредитної і банківської політики;

- створення інформаційно-аналітичної бази для моніторингу показників безпеки банківських установ як основи для всебічного аналізу, прогнозування, моделювання ситуацій та процесів, підготовки відповідних матеріалів, рекомендацій для державних органів, саморегулюючих організацій та окремих комерційних банків;

- реструктуризація існуючого банківського сектора національної економіки шляхом проведення активної політики щодо збільшення капіталізації існуючих банківських установ, злиття та поглинання 3 метою підвищення платоспроможності, фінансової стійкості та стабільності, конкурентоспроможності всіх комерційних банків та банківського сектору в цілому;

- активізація власних джерел розвитку комерційних банків шляхом впровадження відповідних стимулів 3 боку Уряду та Національного банку України (стимулювання попиту (наприклад, купівля нових автомобілів), активізація створення класичних фінансових та промислових груп; субсидіювання кредитів певним секторам внутрішньогосподарського комплексу; підтримка програм кредитування малого бізнесу або іпотеки, допомога позичальникам у складних життєвих ситуаціях, запровадження пільгового оподаткування, впровадження індивідуальних чи групових (для певного типу банків) економічних нормативів i лібералізації резервування); 
- розробка та використання диференційованих, тобто стратегічних (розрахованих на довгострокову перспективу фінансової стабільності), тактичних (розрахованих на середньострокову перспективу - фінансової стабільності) та поточних (короткострокових - тих, дотримання яких свідчить про вирішення нагальних проблем у банківському секторі) показників безпеки банківських установ;

- оцінку рівня достатності забезпечення безпеки банківських установ заходами та ресурсами [8].

Висновки. Фінансова безпека банку $є$ важливим інструментом реалізації його інтересів і пріоритетних цілей, зміцнення його фінансових можливостей для кількісного і якісного зростання, зміцнення його позицій на ринку банківських послуг, забезпечення його нормального функціонування та сталого розвитку в умовах посиленої макроекономічної нестабільності, збільшення зовнішніх і внутрішніх загроз. Надання чіткого визначення поняттю «фінансова безпека банку» дозволить всебічно визначити і описати загальні вимоги до самооборони, саморозвитку і самозбереження внутрішнього банківського сектора в контексті глибоких структурних економічних перетворень в світі. Усвідомлення внутрішніх i зовнішніх загроз створить надійну систему забезпечення фінансової безпеки банку. Розробка ефективного механізму підвищення фінансової безпеки банку повинна ґрунтуватися на оцінці загроз цій безпеці. Повнота, своєчасність і ефективність заходів управління для усунення, попередження та запобігання існуючих і потенційних загроз для банківської системи значною мірою залежать від адекватної оцінки існуючого рівня банківської безпеки.

1. Васильчак С. В., Моцьо Р. Ю. Економічна безпека банків та методи ії забезпечення. Науковий вісник НЛтУ України : зб. наук.-техн. праць. Львів : РВВ НЛтУ України, 2009. Вип. 19.12. С. 287-293. 2. Голобородько Ю. О. Теоретичні підходи до розкриття сутності та складових фінансової безпеки банківських установ. Науковий вісник НЛтУ України. 2012. Вип. 22.12. С. 194-198. 3. Добрик Л. О., Запорожець Г. В. Фінансова безпека банку як складова його стійкості. Ефективна економіка : електронне наукове фахове видання. 2014. № 6. URL: http://www.economy.nayka.com.ua/?op=1\&z=3116 (дата звернення: 05.01.2020). 4. Донець Л.І. Обґрунтування господарських рішень та оцінювання ризиків. Київ : Центр учбової літератури, 2012. 472 с. 5. Євченко Н. Г., Криклій О. А. Вплив податкових ризиків на фінансову безпеку банку. Проблеми і перспективи розвитку банківської системи України : зб. наук. праць. Суми : ДВНЗ «УАБС НБУ», 2009. Вип. 25. С. 45-52. 6. Зачосова Н. В. Особливості забезпечення фінансової безпеки комерційних банків в Україні. Науковий вісник: Фінанси, банки, інвестиції. 2011. № 4. C. 74-78. 7. Звіт про фінансову стабільність НБУ, грудень 2019 року : вебсайт. URL: https://bank.gov.ua/admin_uploads/article/FSR_2019-H2.pdf?v=4 (дата звернення: 05.01.2020). 8. Крупка І. М. Фінансово-економічна безпека банківської системи 
України та перспективи розвитку національної економіки. Бізнесінформ. 2012. № 6. С. 168-175. 9. Момот Т. В., Овчелупова О. М., Соловйова К. С. Оцінка рівня фінансово-економічної безпеки банківських установ в умовах кризи. Комунальне господарство міст : наук.-техн. зб. / Харків. нац. ун-т міськ. госп-ва ім. О. М. Бекетова. Харків : ХНУМГ ім. О. М. Бекетова, 2015. Вип. 125. С. 32-36. 10. Показники банківської системи України : вебсайт. URL: https://bank.gov.ua/statistic/supervision-statist/data-supervision\#1 (дата звернення: 05.01.2020). 11. Соловйов В.І. Банківська безпека України: вдосконалення методики оцінки. Вісник Бердянського університету менеджменту $i$ бізнесу. 2012. № 1(17). С. 171-176. 12. Стрельбицька Л. М., Стрельбицький М. П., Гіжевський В. К. Банківське безпекознавство : навч. посіб. Нац. акад. СБУ, Унів. економіки та права «КРОК» Київ: Вид-во «Кондор», 2007. 602 с.

\section{REFERENCES:}

1. Vasylchak S. V., Motso R. Yu. Ekonomichna bezpeka bankiv ta metody yii zabezpechennia. Naukovyi visnyk NLTU Ukrainy : zb. nauk.-tekhn. prats. Lviv : RVV NLTU Ukrainy, 2009. Vyp. 19.12. S. 287-293. 2. Holoborodko Yu. O. Teoretychni pidkhody do rozkryttia sutnosti ta skladovykh finansovoi bezpeky bankivskykh ustanov. Naukovyi visnyk NLTU Ukrainy. 2012. Vyp. 22.12. S. 194-198. 3. Dobryk L. O., Zaporozhets H. V. Finansova bezpeka banku yak skladova yoho stiikosti. Efektyvna ekonomika : elektronne naukove fakhove vydannia. 2014. № 6. URL: http://www.economy.nayka.com.ua/?op=1\&z=3116 (data zvernennia: 05.01.2020). 4. Donets L. I. Obgruntuvannia hospodarskykh rishen ta otsiniuvannia ryzykiv. Kyiv : Tsentr uchbovoï literatury, 2012. 472 s. 5. Yevchenko N. H., Kryklii O. A. Vplyv podatkovykh ryzykiv na finansovu bezpeku banku. Problemy i perspektyvy rozvytku bankivskoi systemy Ukrainy : zb. nauk. prats. Sumy : DVNZ «UABS NBU», 2009. Vyp. 25. S. 45-52. 6. Zachosova N. V. Osoblyvosti zabezpechennia finansovoi bezpeky komertsiinykh bankiv v Ukraini. Naukovyi visnyk: Finansy, banky, investytsii. 2011. № 4. S. 74-78. 7. Zvit pro finansovu stabilnist NBU, hruden 2019 roku : veb-sait. URL: https://bank.gov.ua/admin_uploads/article/FSR_2019-H2.pdf?v=4 (data zvernennia: 05.01.2020). 8. Krupka I. M. Finansovo-ekonomichna bezpeka bankivskoi systemy Ukrainy ta perspektyvy rozvytku natsionalnoi ekonomiky. Biznesinform. 2012. № 6. S. 168-175. 9. Momot T. V., Ovchelupova O. M., Soloviova K. S. Otsinka rivnia finansovoekonomichnoi bezpeky bankivskykh ustanov $v$ umovakh kryzy. Komunalne hospodarstvo mist : nauk.-tekhn. zb. / Kharkiv. nats. un-t misk. hosp-va im. 0. M. Beketova. Kharkiv : KhNUMH im. 0. M. Beketova, 2015. Vyp. 125. S. 32-36. 10. Pokaznyky bankivskoi systemy Ukrainy : veb-sait. URL: https://bank.gov.ua/statistic/supervision-statist/data-supervision\#1 (data zvernennia: 05.01.2020). 11. Soloviov V. I. Bankivska bezpeka Ukrainy: vdoskonalennia metodyky otsinky. Visnyk Berdianskoho universytetu menedzhmentu i biznesu. 2012. № 1(17). S. 171-176. 12. Strelbytska L. M., Strelbytskyi M. P., Hizhevskyi V. K. Bankivske bezpekoznavstvo : navch. posib. Nats. akad. SBU, Univ. ekonomiky ta prava «KROK» Kyiv : Vyd-vo «Kondor», 2007.602 s. 
Kotyk 0. V., Senior Lecturer of the Finance and Economics of Environmental Management Department,

Liubovska M. M., Senior Student

(National University of Water and Environmental Engineering, Rivne)

\section{THREATS AND RISKS OF FINANCIAL SECURITY OF BANKS AND WAYS TO ELIMINATE THEM}

The banking system is associated with the risk of information leakage, employee abuse, and external threats. The state of the modern domestic financial market, the imperfection of the legislation, the decline in incomes of the population and business, the increase in the unemployment rate are the reasons why new threats to banking activity are emerging. The article defines the concept of «financial security of the bank», given definitions «risk», «threat». The analysis of the relationship of the terms «risk» and «threat». The basic threats of constituents of a bank economic safety and the basic measures of defense and their removals are offered. The classification of threats to the bank's security is observed. It includes exogenous and endogenous factors together with current trends of increasing influence of anthropogenic factors and aggravation of conflicts at various levels, such as military, corporate, stakeholders, bank-staff, and bank-customer. The analysis of the statistics of the banking system functioning under conditions of the current crisis is made. A cricial diagnosis of the banks operations was conducted by the National Bank of Ukraine. In general, to improve the security of banking institutions, the following should be done:

- development of a model of security of banking institutions as a set of officially accepted views, institutions;

- creation of an information-analytical base for monitoring the security of banking institutions;

- restructuring of the existing banking sector of the national economy;

- activation of commercial banks' own sources of development by introducing appropriate incentives by the Government and the National Bank of Ukraine;

- development and use of differentiated, ie strategic, tactical, and current indicators of the security of banking institutions;

- assessment of the level of adequacy of the security of banking institutions by measures and resources.

An adequate level of financial security for banks is possible only if an effective system for detecting, classifying, localizing threats and regulating the risks of the banking system is possible.

Keywords: bank's financial security; threat; risk; external and internal threats to the bank's financial security. 
Котик О. В., старший преподаватель кафедры финансов и экономики природопользования, Любовская М. М., соискатель высшего образования второго

(магистерского) уровня (Национальный университет водного хозяйства и природопользования, г. Ровно)

\section{УГРОЗЫ И РИСКИ ФИНАНСОВОЙ БЕЗОПАСНОСТИ БАНКОВ И ПУТИ ИХ УСТРАНЕНИЯ}

В статье определено содержание понятия «финансовая безопасность банка», рассмотрены определения «риск», «угроза». Проведен анализ взаимосвязи терминов «риск» и «угроза». Проанализированы основные угрозы составляющих финансовой безопасности банка, определено их приоритетность и предложены основные мероприятия их защиты и устранения. Рассмотрена классификация угроз банковской безопасности, формируемых экзо- и эндогенными факторами, с учетом современных тенденций роста влияния техногенных факторов и обострения конфликтов разных уровней, таких как военные, корпоративные, учредительные, банк персонал, банк - клиент. Проведен анализ статистических данных работы банковской системы в современных кризисных условиях. Выполнен критический анализ диагностики деятельности банков, которая была проведена Национальным банком Украины.

Ключевые слова: финансовая безопасность банка; угроза; риск; внешние и внутренние угрозы финансовой безопасности банка. 